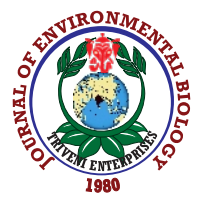

\title{
Studies on insect diversity in jasmine (Jasminum sambac L.) ecosystem
}

\author{
U. Pirithiraj', R.P. Soundararajan ${ }^{2 *}$, C.G.L. Justin ${ }^{1}$ and V. Lakshmanan ${ }^{3}$ \\ ${ }^{1}$ Department of Plant Protection, Anbil Dharmalingam Agricultural College and Research Institute, Tiruchirappalli - 620027 \\ ${ }^{2}$ Horticultural College and Research Institute for Women, Tiruchirappalli - 620027 \\ ${ }^{3}$ Department of Vegetable Science, Horticultural College and Research Institute for Women, Tiruchirappalli - 620027 \\ *Corresponding Author Email : sound73insect@gmail.com
}

\section{Abstract}

Aim: Study was carried out to record the abundance and diversity of insects in jasmine (Jasminum sambac L.) ecosystem.

Methodology: To determine insect pests, natural enemies and non-insect diversity, fortnight observations were taken from second fortnight of September'19 to March'20 on insect population at three adjacent locations. Abundance and diversity indices were computed using mean data. The management practices, presence of weeds and adjacent cropping systems were also recorded at three locations to determine the reasons for variation in the diversity of organisms.

Results: A total of 3335 individuals arthropods belonging to 55 species, which included 32 species of herbivores and 23 species of natural enemies were recorded throughout the study period. Location 3 had perennial crops in the vicinity, un-weeded ecosystem with no chemical inputs. Among various diversity indices calculated, Margalef Richness Index of herbivores was higher at location $3(1.67)$ than location $1(1.17)$ and 2 (0.76).

Interpretation: The abundance and diversity of insects in different jasmine ecosystem depends on the chemical inputs and adjacent cropping system.

Key words: Arthropods, Diversity indices, Insects, Jasmine

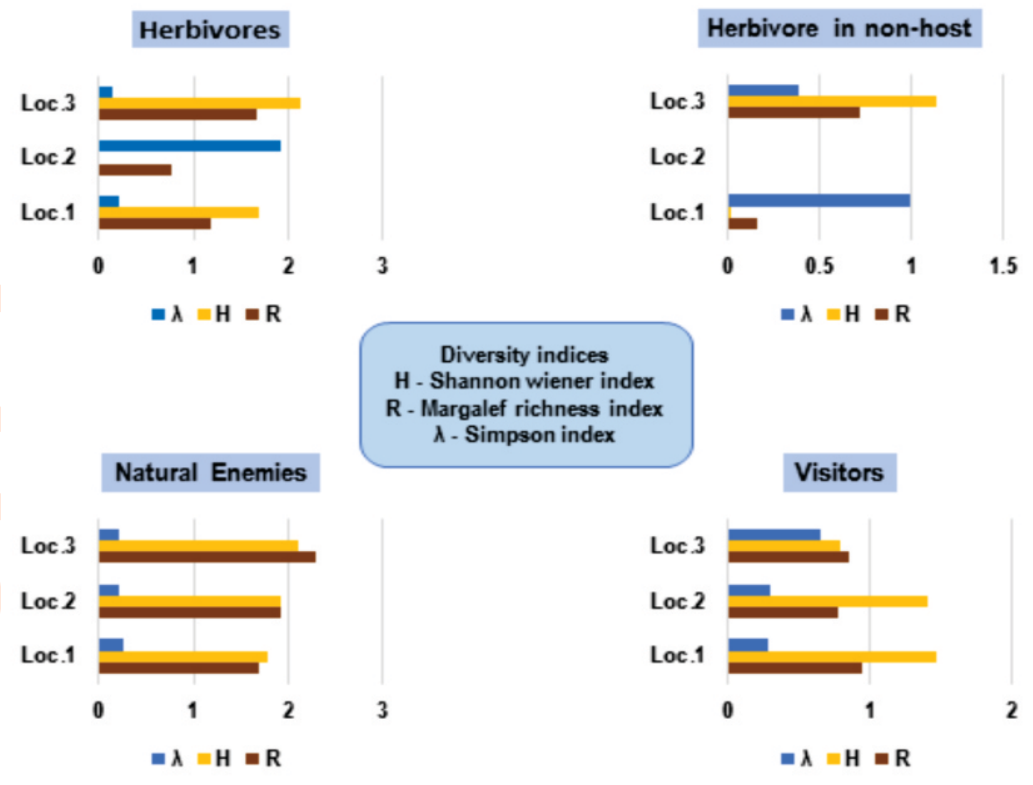

How to cite : Pirithiraj, U., R.P. Soundararajan, C.G.L. Justin and V. Lakshmanan: Studies on insect diversity in jasmine (Jasminum sambac L.) ecosystem. J. Environ. Biol., 42, 1470-1477 (2021). 


\section{Introduction}

Jasmine is one of the leading traditional flower crop in India. The annual production is worth more than 120 million (Lavanya et al., 2014). In India, Tamil Nadu is the leading producer of jasmine with an annual production of 77,247 tonnes cultivated from 9,360 ha (Latha and Pichumani, 2018). Among 200 species of Jasminum genus, the species Jasminum sambac $L$. is an evergreen shrub and native habitat of humid tropical climate. It harbors many insects, since most of the insects are indulged with terrestrial ecosystems. Insects are crucial component of an ecosystem, as they perform many functions like aerating soil, pollinating flowers, pests, predators and parasitoids (Hickman and Wratten, 1996; Baggen and Gurr, 1998; AbouAwad, 1998).

Insect abundance and diversity in a location over a period of time needs to be considered for exploring their spatial variation in biodiversity (Dornelas and Daskalova, 2020). In the metaanalysis of terrestrial and freshwater ecosystem, Van Klink et al. (2020) reported 9 per cent decline in abundance of terrestrial insects. Some recent studies have reported that insect abundance and biomass, even common species, are rapidly declining, which has led to an "Insect Apocalypse" (Biesmeijer et al., 2006; Dirzo et al., 2014; Fox et al., 2014; Hallmann et al., 2017; Goulson, 2019; Montgomery et al., 2020; Sisterson et al., 2020; Harvey et al., 2020). For many crop ecosystems, limited data is available on abundance and diversity of insects that are neither crop pests nor natural enemies. Therefore, there is a dire need to study the insect diversity. Insect diversity index provides valuable information on the rare features and similarities of species in a community (Jaganmohan et al., 2013; Kapkoti et al., 2016). Hence, studying insect's diversity is considered as ecologically, socially and economically important.

Jasmine is omamental plant of economic significance. Value added products like essential oils obtained from jasmine flowers, earn foreign exchange. Very less reports are available on insect diversity of jasmine ecosystems. Utilization of synthetic chemicals play a vital role in lives of agro-ecosystem. The pesticides sprayed fields were noticed with low arthropod diversity than unsprayed fields (Amalin et al., 2009). Jasmine ecosystems usually receive more quantity of synthetic pesticide as flowers are plugged for day-today earnings. Generally, pest management mainly depends on pesticides in agro-ecosystem but it causes several adverse effects. The alternatives strategies such as use of biological control is proved eco-friendly and that can be achieved through documentation of predators and parasitoids. Conservation biological control depends entirely on natural enemies of the pests and it is more adapted to deal with their targets (Ehler, 1998). Conservation of natural enemies is the first step in biological control before standardizing. By following conservation of natural enemies other expenses such as pesticides and labor costs can be saved (New and New, 2009;
Samways et al., 2010). The available natural enemies or in the absence of such organisms can be further encouraged by augmenting through inundative or inoculative release methods (Van Lenteren, 2000). Augmentation is an environmentallysound, viable alternative to chemicals and offers local employment (Bentley and Oneil, 1997). Annual or perennial plants in the field vicinity also play a significant role in maintaining the insect diversity of an ecosystem. The densities of the predators of insect pests in crop fields may be increased by these adjacent habitats because they could provide shelter, breeding sites and sources of alternative food (Dennis et al., 2000). The present work was carried out to explore the diversity of insect in different jasmine ecosystem by assessing the population, diversity indices and factors influencing diversity in different fields.

\section{Materials and Methods}

Field studies were conducted in J. sambac fields located at Sevandhanagar (Location 1), Navalurkuttapattu (Location 2) and Horticulture College Farm, Tamil Nadu Agricultural University, Trichy district (Location 3) from second fortnight of September'19 to second fortnight of March'20. The observations on insect pests as well as non-insect pest including natural predators were taken at fortnightly interval. Each field was marked with 25 cents of land area and ten plants were randomly selected and tagged for observation.

Population of different arthropod species viz., insect herbivores, insect and non-insect natural predators, visitors were observed and recorded as per standard protocol (Chen et al., 2010). In situ observations were taken for the immature and adult stages of the insects. Soil dwelling insects were recorded using pitfall traps from soil surface near the plants and expressed as numbers/trap. Two pitfall traps were placed in each field near the tagged plant. Adult stages of aerial fliers like Odonata and Lepidoptera were visually observed and recorded.

Herbivores and natural enemies harboured on the nonhost plants and weed species in the vicinity of jasmine gardens were also observed. Density of weed species in the fields were also recorded qualitatively. The crops raised or present in the adjacent field and ecosystems and the cultural practices followed in the fields were recorded. At location 3, jasmine garden was maintained without any, chemical and under un-weeded natural condition.

Statistical analyses : Mean population was computed for each individual species observed in the field with standard deviation. Relative abundance was calculated taxonomic order wise as suggested by Singh and Rai (2000). Insect diversity indices were reckoned using Simpson Indices (Simpson, 1949), Shannon Wiener Indices (Shannon and wiener, 1949) and Margalef Richness Index (Margalef, 1958). 


\section{Results and Discussion}

The diversity of herbivores in different jasmine fields revealed higher number of herbivore species in location 3 (14 species) than location 1 (10 species) and 2 (7 species). The individual insect population during the study was higher in college farm (location 3). Sevandhanagar (location 1) field was dominated by blossom midge, Contarinia maculipennis (Felt) with a mean population of 14.7 number of individuals followed by white fly, Dialerodes kirkalydi (Kotinsky) and bud worm, Hendicasis duplifascialis (Hampson) with mean population of 14.5 and 6.53 number of individuals, respectively (Table 1). In location 1, the relative abundance of herbivore was higher $(30.7 \%)$ in the insect order Diptera followed by Hemiptera $(30.2 \%)$, Lepidoptera $(23.8 \%)$ and least with Coleoptera $(0.32 \%)$. The college farm showed high species richness and species evenness than farmer's field at Sevandhanagar and Navalurkuttappattu. The Shannon Index Value of 2.13 was recorded in the college farm field. Margalef Richness Index supports the Shannon index calculation by indicating higher richness in location 3 (1.67) than location 1 (1.17) and 2 (0.76). Adelusi et al. (2018) worked out on insect diversity from five different sites in Benue state of Nigeria. The study have shown with higher Margalef species richness index of 1.86 from site Gyado Villa than other four sites. Shannon wiener diversity of herbivores obtained in bhendi ecosystem during kharif and rabi season was 2.286 and 2.294 respectively. This indicates that the diversity of herbivores was similar during both the seasons (Chakraborty et al., 2014).

Among different natural predators, the species Lasius niger (Linnaeus) was predominant in first location with mean population of 9.00 followed by Meranoplus bicolor (Guerin) ( 5.38 mean population). The predator carabid was recorded from pitfall trap. Location 3 had seven species of non-insect natural predators, among which Therrididae was found with higher number of individual population (Table 2). Relative abundance of natural enemies in first location was higher in the group Hymenoptera (72.3\%) followed by Diptera (11.3\%) and Odonata (7.09\%). The second location was dominated by Hymenoptera with relative abundance of 52.2 per cent followed by Odonata (32.74\%) and Diptera (7.96\%). Location 3 was also higher in Hymenoptera (61.5\%) followed by Araneae (23.3\%) and Diptera $(6.17 \%)$. Minimum relative abundance was recorded in Dictyoptera (1.14\%) and Coleoptera (1.37\%). Simpson Index (0.20), Shannon Wiener Index (2.10) and Margalef Species Richness Index (2.30) indicates that diversity of natural predators in college farm was higher than the other two locations.

Visitors have no role, neither herbivores nor natural predators in an ecosystem. Some literatures suggest visitor insects as tourist (Kevan and Baker, 1983; Hespenheide, 1985; Causton et al., 2006). Insect visitor are known as insects just passes through the field and they wouldn't depend the crops for food or oviposition. In particular they do not have any significant role in the crop ecosystem. In some literatures these visitors are often mentioned as tourist insects. In the present study, Tanytarsus sp. (Chironomidae) was higher in Sevandhanagar with mean population of 2.46 , while Navalurkuttappattu was dominated by Papilio sp. (Papilionidae) with mean population of 2.53 (Table 3). In first and second location, the visiting Lepidoptera (50.6 and 65\%) was relatively abundant than other orders. Location 3 was abundant with Diptera (31.25\%) followed

Table 1 : Population of herbivorous insect occurrence in different jasmine fields

\begin{tabular}{|c|c|c|c|c|c|c|}
\hline \multirow[t]{2}{*}{ Order } & \multirow[t]{2}{*}{ Family } & \multirow[t]{2}{*}{ Common name/Genus/Species } & \multirow{2}{*}{$\begin{array}{l}\text { Stage of insect } \\
\text { observed }\end{array}$} & \multicolumn{3}{|c|}{ Location (Mean of 13 observations) } \\
\hline & & & & 1 & 2 & 3 \\
\hline \multicolumn{7}{|c|}{ Insect herbivores (I - Immature stage, A - Adult) } \\
\hline \multirow[t]{2}{*}{ Lepidoptera } & Crambidae & Hendicasis duplifascialis (Hampson) & I & $6.53 \pm 2.19$ & $5.76 \pm 1.18$ & $3.53 \pm 2.64$ \\
\hline & & Nausinoe geometrialis (Guenee) & I & $4.92 \pm 1.78$ & $5.92 \pm 1.40$ & $4.84 \pm 1.86$ \\
\hline \multirow[t]{5}{*}{ Hemipteran } & Aleyrodidae & Dialerodes kirkalydi(Kotinsky) & I\&A & $14.5 \pm 7.78$ & $17.7 \pm 7.81$ & $0.84 \pm 0.32$ \\
\hline & Pentatomidae & Nezara viridula(Linnaeus) & A & 0.00 & 0.00 & $0.76 \pm 0.36$ \\
\hline & & Antestiposis cruciate (Fabricius) & I\&A & 0.00 & 0.00 & $1.00 \pm 0.75$ \\
\hline & Tingidae & Corythanma ayyari (Drake) & I\&A & 0.00 & 0.00 & $1.30 \pm 0.69$ \\
\hline & Coreidae & Riptortus pedestris (Fabricius) & I\&A & 0.00 & 0.00 & $0.30 \pm 0.16$ \\
\hline \multirow[t]{3}{*}{ Orthoptera } & Acrididae & Anacridium flavascens (Fabricius) & I\&A & $0.30 \pm 0.29$ & 0.00 & $1.30 \pm 0.44$ \\
\hline & Pyrgomorphidae & Neorthocris sp. & I\&A & $0.15 \pm 0.14$ & 0.00 & $1.07 \pm 0.46$ \\
\hline & Acrididae & Oxya nitidula(Walker) & $I \& A$ & 0.00 & 0.00 & $0.07 \pm 0.07$ \\
\hline Diptera & Cecidomyiidae & Contarinia maculipennis (Felt) & I & $14.7 \pm 5.79$ & $15.9 \pm 6.22$ & $5.76 \pm 4.48$ \\
\hline Thysanoptera & Thripidae & Frankliniella scultzei(Trybom) & $I \& A$ & $0.15 \pm 0.14$ & $0.07 \pm 0.07$ & $11.7 \pm 9.74$ \\
\hline Hymenoptera & Megachilidae & Megachile sp. & A & $0.61 \pm 0.23$ & $0.07 \pm 0.07$ & 0.00 \\
\hline Phasmida & Lonchodidae & Carausius morosus (Br) & 1 & 0.00 & 0.00 & $0.15 \pm 0.10$ \\
\hline \multicolumn{7}{|c|}{ Non insect herbivore (I - Immature stage, A - Adult) } \\
\hline Trombidiformes & Tetranychidae & Tetranychus urticae (Koch) & I\&A & $5.92 \pm 4.87$ & $9.07 \pm 2.84$ & $25.4 \pm 11.1$ \\
\hline
\end{tabular}


by Lepidoptera (17.3\%). Simpson Index of visitors was higher in location 3 than other fields. Shannon Wiener Index obtained for visitors in locations 1, 2 and 3 were 1.47, 1.40 and 0.78, respectively. Eventhough more population of individuals and species present in location 3 , the calculated indices indicated that the species richness and evenness was higher in first location. This was because more number of individuals in college farm (location 3) was not evenly distributed. The higher population of individual insect in location 3 was mainly because of abundance of only one species, Tanytarsus sp.. This uneven and huge variation in distribution of individuals among the species in college farm might be a reason for the lower Shannon wiener diversity index. Margalef richness index of visitors is also higher for Sevandhanagar than Navalurkuttappattu and college farm due to similar reasons. Species richness of native bees were reported from urban green space (Bhatta and Kumar, 2020).

Comparing other groups of insect's viz., herbivore of jasmine, natural enemies and visitors, herbivores on weeds were found with minimum population and number of species. The weed plants in adjacent locations were also recorded qualitatively. In college farm Brevenia rehi Lindinger (1.30) was predominant but also had populations of Oxyrachis tarandus (Fabricius), Aegocera venulia (Cramier), Spodoptera litura (Fabricius) and bag worm. Simpson, Shannon wiener and Margalef species richness index indicates the high species diversity of herbivores on non-host crops in college farm than Sevandhanagar and Navalurkuttappattu.

It was clearly evident that variation was noticed in the diversity of insect pests and natural enemies in three jasmine ecosystems. In first two locations farmers used different pesticides for the management of insect pests at a frequency of 15 to 20 days interval. The pesticide groups such as organophosphates, synthetic pyrethroids and neonicotinoids were mostly used by them. At location 1, profenofos $40 \%+$ cypermethrin 4\% EC, monocrotophos 36\% SL, thiamethoxom $12.6 \%$ + lambda cyhalothrin $9.5 \%$ ZC, phenthoate $50 \%$ EC and dichlorvos $76 \%$ EC were regularly used. Apart from these insecticides, zinc containing dithiocarbamate, propineb $70 \mathrm{WP}$ fungicide compounds were used for managing the plant pathogenic fungus in the field. For promoting beneficial microorganisms and water holding capacity of soil, humic acid 15 $\%$ were sprayed. In second location, insecticides mostly belongs to phenylpyrazole, analogs of nereistoxin, pyrethroids and organothiophosphates were used. The insecticides such as fipronil $5 \%$ SC, deltamethrin 2.8\% EC, cartap hydrochloride 50\% SP, cypermethrin $3 \%+$ quinolphos 20 EC were used for managing insect pests. Pesticides affects the abundance and diversity of non-targeted insects (Rands and Sotherton, 1986; Marko et al., 2009; Muratet and Fontaine, 2015).

Table 2 : Population of natural predators in adjacent jasmine fields

\begin{tabular}{|c|c|c|c|c|c|c|}
\hline \multirow[t]{2}{*}{ Order } & \multirow[t]{2}{*}{ Family } & \multirow[t]{2}{*}{ Common name/Genus/Species } & \multirow{2}{*}{$\begin{array}{l}\text { Stage of insect } \\
\text { observed }\end{array}$} & \multicolumn{3}{|c|}{ Location (Mean of 13 observations) } \\
\hline & & & & 1 & 2 & 3 \\
\hline \multicolumn{7}{|c|}{ Insect predators and parasitoids (I - Immature stage, A - Adult) } \\
\hline \multirow[t]{6}{*}{ Hymenoptera } & Vespidae & Ropalidia sp. & A & $0.53 \pm 0.23$ & $0.23 \pm 0.15$ & $0.38 \pm 0.17$ \\
\hline & Torymidae & Microdontomerussp. & $A$ & $0.38 \pm 0.36$ & $0.30 \pm 0.22$ & $0.76 \pm 0.59$ \\
\hline & Formicidae & Lasius niger(Linnaeus) & $A$ & $9.00 \pm 4.26$ & $1.46 \pm 0.96$ & $10.7 \pm 4.13$ \\
\hline & Formicidae & Meranoplus bicolor(Guerin) & $A$ & $5.38 \pm 3.42$ & $2.30 \pm 1.53$ & $8.15 \pm 4.06$ \\
\hline & Braconidae & Apantelessp. & $A$ & $0.38 \pm 0.25$ & 0.00 & 0.00 \\
\hline & Ichneumonidae & Ichneumonid parasitoid & $A$ & 0.00 & $0.23 \pm 0.22$ & $0.61 \pm 0.41$ \\
\hline \multirow[t]{3}{*}{ Diptera } & Sarcophagidae & Flesh flies & $A$ & $1.84 \pm 0.45$ & $0.07 \pm 0.07$ & $0.15 \pm 0.14$ \\
\hline & Dolicophodidae & Dolichopussp. & $A$ & $0.53 \pm 0.31$ & $0.53 \pm 0.51$ & $1.92 \pm 1.05$ \\
\hline & Asilidae & Robber fly & $A$ & $0.07 \pm 0.07$ & $0.07 \pm 0.07$ & 0.00 \\
\hline \multirow[t]{2}{*}{ Odonata } & Libellulidae & Orthetrum Sabina (Drury) & $A$ & $1.38 \pm 0.51$ & $2.69 \pm 0.72$ & $0.91 \pm 0.21$ \\
\hline & Coenagrionidae & Ischnurasp. & A & $0.15 \pm 0.14$ & $0.15 \pm 0.14$ & $0.76 \pm 0.36$ \\
\hline Dictyoptera & Mantidae & Praying mantis & $I \& A$ & $0.30 \pm 0.16$ & $0.15 \pm 0.14$ & $0.38 \pm 0.25$ \\
\hline Neuroptera & Chrysopidae & Chrysoperla cornea (Stephens) & I & $0.46 \pm 0.23$ & $0.15 \pm 0.14$ & 0.00 \\
\hline Coleoptera & Coccinellidae & Cheilomenes sexmaculata (Fabricius) & $A$ & 0.00 & $0.15 \pm 0.14$ & $0.46 \pm 0.20$ \\
\hline \multicolumn{7}{|c|}{ Non insect predators (I - Immature stage, A - Adult) } \\
\hline \multirow[t]{7}{*}{ Araneae } & Araneidae & Orb weaver & I\&A & $0.15 \pm 0.14$ & 0.00 & $0.30 \pm 0.29$ \\
\hline & Therrididae & Tangle web spider & $I \& A$ & 0.00 & 0.00 & $6.92 \pm 2.04$ \\
\hline & Thomisidae & Crab spider & $I \& A$ & 0.00 & 0.00 & $0.30 \pm 0.22$ \\
\hline & Tetragnathidae & Long jawed spider & $I \& A$ & 0.00 & 0.00 & $0.23 \pm 0.15$ \\
\hline & Oxyopidae & Oxyopessp. & $I \& A$ & 0.00 & 0.00 & $0.23 \pm 0.15$ \\
\hline & Salticidae & Opisthoncus sp. & $I \& A$ & 0.00 & 0.00 & $0.15 \pm 0.14$ \\
\hline & Salticidae & Jumping spider & $I \& A$ & 0.00 & 0.00 & $0.46 \pm 0.31$ \\
\hline
\end{tabular}


Table 3 : Population of insect visitors in adjacent ecosystem of jasmine fields

\begin{tabular}{|c|c|c|c|c|c|c|}
\hline \multirow[t]{2}{*}{ Order } & \multirow[t]{2}{*}{ Family } & \multirow[t]{2}{*}{ Common name/Genus/Species } & \multirow{2}{*}{$\begin{array}{l}\text { Stage of insect } \\
\text { observed }\end{array}$} & \multicolumn{3}{|c|}{ Location (Mean of 13 observations) } \\
\hline & & & & 1 & 2 & 3 \\
\hline \multicolumn{7}{|c|}{ Insect visitors (I - Immature stage, A - Adult) } \\
\hline \multirow[t]{5}{*}{ Lepidoptera } & Pieridae & Eurema hecabe (Linnaeus) & A & $1.46 \pm 0.46$ & $0.23 \pm 0.22$ & $0.46 \pm 0.25$ \\
\hline & Papilonidae & Papilio sp. & $A$ & $0.53 \pm 0.23$ & $2.53 \pm 2.20$ & $0.23 \pm 0.11$ \\
\hline & Lycaenidae & Lampides boetics (Linnaeus) & $A$ & $0.69 \pm 0.45$ & $0.92 \pm 0.33$ & $1.07 \pm 0.51$ \\
\hline & Hesperidae & Pelopidas mathias (Fabricius) & $A$ & $0.15 \pm 0.14$ & 0.00 & $0.15 \pm 0.10$ \\
\hline & Nymphalidae & Danaus plexippus (Linnaeus) & A & 0.00 & $0.30 \pm 0.29$ & 0.00 \\
\hline Hemiptera & Pyrhocoridae & Dysdercus cingulatus (Fabricius) & $I \& A$ & 0.00 & 0.00 & $0.23 \pm 0.15$ \\
\hline \multirow[t]{2}{*}{ Coleoptera } & Chrysomelidae & Aulocaphora foveicolis (Lucas) & A & 0.00 & $0.23 \pm 0.22$ & 0.00 \\
\hline & Buprestidae & Jewele beetle & A & $0.07 \pm 0.07$ & 0.00 & 0.00 \\
\hline \multirow[t]{2}{*}{ Diptera } & Chironomidae & Tanytarsus sp. & $A$ & $2.46 \pm 1.32$ & $1.92 \pm 1.34$ & $8.84 \pm 4.74$ \\
\hline & Tipulidae & Crane flies & $A$ & $0.23 \pm 0.15$ & 0.00 & 0.00 \\
\hline Hymenoptera & Apidae & Apis cerana indica (Fabricius) & $A$ & 0.00 & 0.00 & $0.07 \pm 0.07$ \\
\hline
\end{tabular}

Table 4 : Relative abundance of various insect groups in different jasmine ecosystem

\begin{tabular}{|c|c|c|c|c|c|c|c|c|c|c|c|c|}
\hline \multirow[t]{3}{*}{ Order } & \multicolumn{12}{|c|}{ Relative Abundance } \\
\hline & \multicolumn{4}{|c|}{ Location 1} & \multicolumn{4}{|c|}{ Location 2} & \multicolumn{4}{|c|}{ Location 3} \\
\hline & $\mathrm{H}$ & $\mathrm{Hn}$ & NE & V & $\mathrm{H}$ & $\mathrm{Hn}$ & NE & V & $\mathrm{H}$ & $\mathrm{Hn}$ & NE & V \\
\hline Lepidoptera & 23.8 & 0.00 & 0.00 & 50.6 & 21.9 & 0.00 & 0.00 & 65.0 & 14.3 & 18.4 & 0.00 & 17.3 \\
\hline Hemiptera & 30.2 & 100.0 & 0.00 & 0.00 & 30.7 & 0.00 & 0.00 & 0.00 & 7.26 & 81.5 & 0.00 & 2.08 \\
\hline Orthoptera & 0.96 & 0.00 & 0.00 & 0.00 & 0.00 & 0.00 & 0.00 & 0.00 & 4.22 & 0.00 & 0.00 & 0.00 \\
\hline Diptera & 30.7 & 0.00 & 11.3 & 47.9 & 29.9 & 0.00 & 7.96 & 31.25 & 9.90 & 0.00 & 6.17 & 79.8 \\
\hline Trombidiformes & 12.3 & 0.00 & 0.00 & 0.00 & 17.0 & 0.00 & 0.00 & 0.00 & 43.7 & 0.00 & 0.00 & 0.00 \\
\hline Coleoptera & 0.32 & 0.00 & 2.96 & 1.36 & 0.00 & 0.00 & 1.76 & 3.75 & 0.00 & 0.00 & 1.37 & 0.00 \\
\hline Hymenoptera & 1.28 & 0.00 & 72.3 & 0.00 & 0.14 & 0.00 & 52.2 & 0.00 & 0.00 & 0.00 & 61.5 & 0.69 \\
\hline Araneae & 0.00 & 0.00 & 0.70 & 0.00 & 0.00 & 0.00 & 0.00 & 0.00 & 0.00 & 0.00 & 23.3 & 0.00 \\
\hline Thysanoptera & 0.32 & 0.00 & 0.00 & 0.00 & 0.14 & 0.00 & 0.00 & 0.00 & 20.2 & 0.00 & 0.00 & 0.00 \\
\hline Odonata & 0.00 & 0.00 & 7.09 & 0.00 & 0.00 & 0.00 & 32.74 & 0.00 & 0.00 & 0.00 & 4.80 & 0.00 \\
\hline Neuroptera & 0.00 & 0.00 & 2.12 & 0.00 & 0.00 & 0.00 & 1.76 & 0.00 & 0.00 & 0.00 & 0.00 & 0.00 \\
\hline Dictyoptera & 0.00 & 0.00 & 1.41 & 0.00 & 0.00 & 0.00 & 1.76 & 0.00 & 0.00 & 0.00 & 1.14 & 0.00 \\
\hline Phasmida & 0.00 & 0.00 & 0.00 & 0.00 & 0.00 & 0.00 & 0.00 & 0.00 & 0.26 & 0.00 & 0.00 & 0.00 \\
\hline Dermaptera & 0.00 & 0.00 & 0.00 & 0.00 & 0.00 & 0.00 & 1.76 & 0.00 & 0.00 & 0.00 & 1.60 & 0.00 \\
\hline
\end{tabular}

${ }^{*} \mathrm{H}$-Herbivores in jasmine; $\mathrm{Hn}$-Herbivores in non-host plants (weeds); NE-Natural predators, $\mathrm{V}$-Visitors

At College Farm (location 3), the jasmine field was maintained without insecticides during the study period. All the chemical insecticides used in location 1 and 2 were targeted for pests of jasmine which included $H$. duplifascialus, $C$. maculipennis, N. geometralis, F. scultzeiand T. urticae. The major pests of jasmine $H$. duplifascialis and C.maculipennis were found with higher number of individuals at location 1 (6.53 and 14.76) and 2 (5.76 and 15.92). In location 3, these pests were recorded with minimum number ( 3.53 and 5.76 ). Even after pesticides use in location 1 and 2, the buildup of population was still befuddled. However general visitors like Eurema hecabe (Linnaeus), Papilio sp., Lampides boetics (Linnaeus), Pelopidas mathias (Fabricius) were also found higher at location 1 than locations 2 and 3 . Geslin et al. (2016) proposed judicious use of pesticides to maintain high flower visiting species.

Spiders as a generalized predator play an important role in the ecosystem (Riechert and Lockley, 1984; Isaac and Kennedy, 2018). The relative abundance of araneae was highest in College Farm (23.3\%), than Sevandhanagar $(0.70 \%)$ and Navalurkuttappattu (0.00). Khan (2012) studied the diversity, abundance and habitat association of spiders on apple orchards in Kashmir and reported high abundance of spiders in unsprayed orchards than in pesticide sprayed orchards. Reduced abundance of spider were reported in the chemical sprayed fields (Pekar, 2012). Less number of spider species were recorded from the chemical treated plots than untreated controls (Fountain et al., 2007). Spiders showed strong pest control effects as they 
Table 5 : Comparison of species richness, evenness and diversity indices of insect in different jasmine fields

\begin{tabular}{llllllll}
\hline Location & Insect groups & $\begin{array}{l}\text { Number of } \\
\text { species (S) }\end{array}$ & $\begin{array}{l}\text { Total number } \\
\text { of individuals } \\
\text { (N) }\end{array}$ & $\begin{array}{l}\text { Relative } \\
\text { abundance } \\
\text { (RA \%) }\end{array}$ & $\begin{array}{l}\text { Margalef } \\
\text { Richness } \\
\text { Index (R) }\end{array}$ & $\begin{array}{l}\text { Shannon } \\
\text { Wiener } \\
\text { Index (H) }\end{array}$ & $\begin{array}{l}\text { Simpson } \\
\text { Index } \\
(\lambda)\end{array}$ \\
\hline Location1 & Herbivores in jasmine & 10 & 625 & 58.46 & 1.17 & 1.68 & 0.22 \\
& Herbivores in non-host plants (weeds) & 1 & 89 & 8.32 & 0.15 & 0.01 & 0.99 \\
& Natural predators & 14 & 282 & 26.37 & 1.69 & 1.79 & 0.25 \\
& Visitors & 7 & 73 & 6.82 & 0.94 & 1.47 & 0.28 \\
Location2 2 & Herbivores in jasmine & 7 & 692 & 78.19 & 0.76 & 1.45 & 0.26 \\
& Herbivores in non-host plants (weeds) & 0 & 0 & 0 & - & - & - \\
& Natural predators & 14 & 113 & 12.76 & 1.92 & 1.92 & 0.20 \\
& Visitors & 6 & 80 & 9.03 & 0.77 & 1.40 & 0.29 \\
Location3 3 & Herbivores in jasmine & 14 & 757 & 54.81 & 1.67 & 2.13 & 0.14 \\
& Herbivores in non-host plants (weeds) & 5 & 33 & 2.38 & 0.72 & 1.14 & 0.38 \\
& Natural predators & 19 & 447 & 32.36 & 2.30 & 2.10 & 0.20 \\
& Visitors & 7 & 144 & 10.42 & 0.85 & 0.78 & 0.65 \\
\hline
\end{tabular}

dominated the predator fauna (Kolb et al., 2020). Despite the prominent role of spiders in most ecosystems, they are still endangered and were futile in current conservation efforts (Branco and Cardoso, 2020).

Several studies have reported reduction in population of parasitoids in chemicals applied fields. Berry (1996) reported that use of pesticides in conventional field, significantly reduced the hymenopteran and neuropteran parasitoids. Significantly higher population of parasitoids were noticed in organic fields where pesticides were not used. Similarly, the parasitoid, Microdontomerus sp. of blossom midge was found higher in number at location 3 than location 1 and 2, even though their host insect blossom midge was found higher at locations 1 and 2 than location 3 . Higher predatory coccinellid diversity were recorded in the pesticide unsprayed fields than sprayed ones (Shah and Khan, 2014). Sanchez-Bayo (2011) narrated the impacts of agricultural pesticides on terrestrial ecosystems and mentioned that insecticide sprays can wipe out 99 per cent of the population of target pests as well as those of non-target species, just as chemotherapy kills both bad and good cells alike. Use of agrochemicals negatively affected the parasitoids.

Habitat diversity is an important phenomenon in any ecosystem for the occurrence of insects and other organisms. Recently, ecological engineering strategies have become a concept in the sustenance and maintenance of natural enemies in a cropping system to suit for integrated pest management (Gurr et al., 2004). In the present study at Sevandhanagar (location 1), the surrounding fields had annual crops like chrysanthemum, bhendi and brinjal. Subabul were present at the border of jasmine field. At location 2, adjacent fields crop such as violet cockscomb flower, brinjal and bhendi were noticed during the study period. At this location also subabul was observed as border crop. However, at third location different types of adjacent ecosystem was surrounded by tree crops like guava, sapota, coconut, neerium and ixora. At first two locations, annual crops were noticed at adjacent ecosystem, while at location 3 perennial cropping systems might created differences in the diversity of arthropods.

The relative abundance of Odonata was higher at locations $1(7.01 \%)$ and $2(32.74 \%)$ than location $3(4.80 \%)$ (Table 4). The higher population was encouraged and influenced by the presence of subabul plants at locations 1 and 2, which was absent at location 3. Usually subabul plants had psyllid population for which the Odonatan insects are flying around to feed on the homopteran insects (Joseph and Venkitesan, 1995; Chitra et al., 2002). Crop habitat plays an important role in arrival of pests, visitor insects and natural enemies in any ecosystem. Likewise, presence of annual crops and perennial crops may influence the insect diversity in an ecosystem. The densities of predators of insect pests in crop fields may be increased by these adjacent habitats because they could provide shelter, breeding sites and sources of alternative food (Dennis et al., 2000).

Weeds have greater role in supporting biodiversity in agroecosystem (Marshall et al., 2003). Higher number of weeds was noticed at location 3 than 1 and 2. The third location (45 species) had more number of species than location 1 ( 32 species) and 2 (26 species). The total number of individuals were also higher at location 3 (1381 individuals) than locations 1 (1069 individuals) and 2 (885 individuals), respectively (Table 5). Higher abundance of predatory ladybeetles were noticed in the maize fields which had more weed density and less human disturbances (Yang et al., 2019). Flowering weeds can be utilized as vegetation cover to attract the predators and parasitoids for sustainable pest management (Saenz Romo et al., 2019).

Present study concludes that among different jasmine fields, the third location had more insect diversity, abundance with high number of species as well as individuals in each species. The calculated diversity indices viz., Margalef richness index, 
Shannon Wiener index and Simpson indexes supports higher insect diversity in the location. The particular field was maintained without chemical pesticide might be the reason for the enhanced diversity. In principle, higher diversity will pave way for balanced ecosystem. Conservation and augmentation of natural enemies in such kind of habitat will encourage biological control in managing insect pests.

\section{Acknowledgments}

The authors acknowledge the farmer Th. P. Kumar, Navalurkuttappattu and Th. Sakthivel, Sevandhanagar, Tiruchirappalli, India for accepting and helping to take up the experiment in his field. The authors thank Ms. R. Divya, Department of Entomology, TNAU, Coimbatore for helping in the data analysis. The authors also acknowledge the Dean, HC \& RI (W), TNAU, Tiruchirappalli, Tamil Nadu, India for permitting to conduct the experiment in Horticulture College Farm.

\section{Add-on Information}

Author's contribution : U. Pirithiraj: Conducted the experiment and drafted the manuscript; R.P. Soundararajan: Major advisor who conceptualized the research idea and fine-tuned the manuscript; C.G.L. Justin: Minor advisor, succour in the research work and manuscript preparation; V. Lakshmanan: Minor advisor, co-ordinated in the layout and field experiments.

Research content: The research content of manuscript is original and has not been published elsewhere.

Ethical approval: Not applicable

Conflict of interest: The authors declare that there is no conflict of interest.

\section{Data from other sources: Not applicable}

Consent to publish: All authors agree to publish the paper in Journal of Environmental Biology.

\section{References}

Abou-Awad, B.A., A.A. El-Sherif, M.F. Hassan and M.M. Abou-Eleila: Studies on development, longevity, fecundity and predation of Amblyseius olivi Nasr (Acari: Phytoseiidae) on various kinds of prey and diets. J. Plant Disea. Protec., 105, 538-544 (1998).

Adelusi, S.M., R.T. Ada and E.A. Omudu: Diversity and abundance of insects species in Makurdi, Benue State, Nigeria. Int. J. New Technol. Res., 4, 52-57 (2018).

Amalin, D.M., J.E. Pena, R. Duncan, J. Leavengood and S. Koptur: Effects of pesticides on the arthropod community in the agricultural areas near the Everglades National Park. Proc. Fla. State. Hort. Soc., 122, 429-437 (2009).

Baggen, L.R. and G.M. Gurr: The Influence of food on Copidosoma koehleri (Hymenoptera: Encyrtidae), and the use of flowering plants as a habitat management tool to enhance biological control of potato moth, Phthorimaea operculella (Lepidoptera: Gelechiidae). Biolog. Cont., 11, 9-17 (1998).

Bentley, J.W. and R.J. Oneil: On the ethics of biological control of insect pests. Agricult. Human Val., 14, 283-289 (1997).

Berry, N.A., S.D. Wratten, A. McErlich and C. Frampton: Abundance and diversity of beneficial arthropods in conventional and "organic" carrot crops in New Zealand. New Zealand J. Crop Horticul. Sci., 24, 307-313 (1996)

Bhatta, V.R. and A.N. Kumar: Native bee diversity and abundance in an urban green space in Bengaluru, India. J. Environ. Biol., 41, 1536$1541(2020)$

Biesmeijer, J.C., S.P. Roberts, M. Reemer, R. Ohlemüller, M. Edwards, T. Peeters and J. Settele: Parallel declines in pollinators and insectpollinated plants in Britain and the Netherlands. Science, 313, 351$354(2006)$

Branco, V.V. and P. Cardoso: An expert-based assessment of global threats and conservation measures for spiders. Global Ecol. Conser., 24, 1-26 (2020).

Causton, C.E., S.B. Peck, B.J. Sinclair, L. Roque-Albelo, C.J. Hodgson and B. Landry: Alien insects: Threats and implications for conservation of Galápagos Islands. Ann. Entomol. Soc. Amer., 99, 121-143 (2006).

Chakraborty, A., K. Kumar and N. Chitra: Computation of insects biodiversity in bhendi (Abelmoschus esculentus (L.) Moench) ecosystem. The Bioscan, 9, 1405-1409 (2014).

Chen, Y., Q. Li, Y. Chen, S. Wang and Y. Yang: Lac-production, arthropod biodiversity and abundance, and pesticide use in Yunnan Province, China. Trop. Ecol., 51, 255 (2010).

Chitra, N., K. Gunathilagaraj and R.P. Soundararajan: Habitat selection for oviposition by Pantala flavescens (Fab.) (Libellulidae: Odonata). Zoos'Print J., 17, 957-958 (2002).

Dennis, P., G.L.A. Fry and A. Andersen: The impact of field boundary habitats on the diversity and abundance of natural enemies in cereals. In: Interchanges of insects between agricultural and surrounding landscapes (Eds.: B. Ekbom, M.E. Irwin and Y. Robert). Springer, 1, 195-214 (2000).

Dirzo, R., H.S. Young, M. Galetti, G. Ceballos, N.J. Isaac and B. Collen: Defaunation in the Anthropocene. Science, 345, 401-406 (2014).

Dornelas, M. and G.N. Daskalova: Nuanced changes in insect abundance. Science, 368, 368-369 (2020).

Ehler, L.: Conservation Biological Control. $1^{\text {st }}$ Edn., Academic Press, 397 pages (1998).

Fountain, M.T., V.K. Brown, A.C. Gange, W.O. Symondson and P.J. Murray: The effects of insecticide chlorpyrifos on spider and Collembola communities. Pedobiologia, 51, 147-158 (2007).

Fox, R., T.H. Oliver, C. Harrower, M.S. Parsons, C.D. Thomas and D.B. Roy: Long term changes to the frequency of occurrence of British moths are consistent with opposing and synergistic effects of climate and land use changes. J. App. Ecol., 51, 949-957 (2014).

Geslin, B., M. Oddie, M. Folschweiller, G. Legras, C.L. Seymour, F.F. Van Veen and $E$. Thebault: Spatiotemporal changes in flying insect abundance and their functional diversity as a function of distance to natural habitats in a mass flowering crop. Agricult. Ecosys. Environ., 229, 21-29 (2016).

Goulson, D.: The insect apocalypse, and why it matters. Curr. Biol., 29, 967-971 (2019).

Gurr, G.M., S.L. Scarratt, S.D. Wratten, L. Berndt and N. Irvin: Ecological engineering, habitat manipulation and pest management. CISRO Publishing., Australia, 227 pages (2004). 
Hallmann, C.A., M. Sorg, E. Jongejans, H. Siepel, N. Hofland, H. Schwan and D. Goulson: More than 75 percent decline over 27 years in total flying insect biomass in protected areas. PLOS ONE, 12, e0185809 (2017).

Harvey, J.A., R. Heinen, I. Armbrecht, Y. Basset, J.H. Baxter-Gilbert, T.M. Bezemer and V. Clausnitzer: International scientists formulate a roadmap for insect conservation and recovery. Nat. Ecol. Evol., 4, 174-176 (2020).

Hespenheide, H.A.: Insect visitors to extra-floral nectaries of Byttneria aculeata (Sterculiaceae): Relative importance and roles. Ecolog. Entomol., 10, 191-204 (1985).

Hickman, J.M. and S.D. Wratten: Use of Phelia tanacetifolia strips to enhance biological control of aphids by overfly larvae in cereal fields. J. Econ. Entomol., 89, 832-840 (1996).

Isaac, M.K. and J.S. Kennedy: Assessment on the incidence of twospotted mite of jasmine, Tetranychus urticae Koch, and its natural enemies in Tamil Nadu. Int. J. Acarol., 44, 162-170 (2018).

Jaganmohan, M., L.S. Vailshery and H. Nagendra: Patterns of insect abundance and distribution in urban domestic gardens in Bangalore, India. Diversity, 5, 767-778 (2013).

Joseph, K.J. and T.S. Venkitesan: Predation of the Subabul Psyllid Heteropsylla cubana by the Dragonfly Pantala flavescens in nature. Entomon., 20, 273-276 (1995).

Kapkoti, B., R.K. Joshi and R.S. Rawal: Variations in the abundance and diversity of insects in apple orchards of Kumaun, Western Himalaya, India. Curr. Sci., 110, 438-443 (2016).

Kevan, P.G. and H.G. Baker: Insects as flower visitors and pollinators. Ann. Rev. Entomol., 28, 407-453 (1983).

Khan, A.A.: Comparison of spider diversity in relation to pesticide use in apple orchards of Kashmir. J. Biol. Cont., 26, 1-10 (2012).

Kolb, S., D. Uzman, I. Leyer, A. Reineke and M.H. Entling: Differential effects of semi-natural habitats and organic management on spiders in viticultural landscapes. Agricult., Ecosyst. Environ., 287, 106695 (2020).

Latha, R. and R. Pichumani: An economic study on jasmine cultivation in Ettarai Village in Tiruchirappalli District. Inter. J. Res. Analyt. Rev., 5, 55-59 (2018)

Lavanya, V., U. Nidoni, H. Sharanagouda, C. T. Ramachandra, A. R. Kurubar and V. Ramya: Petal senescence in jasmine flowers (Jasminum sambac) during storage by using different packaging materials and pre-treatment: Role of phenolics. Int. J. Sci. Environ. Technol., 3, 2130-2135(2014).

Margalef, R.: Information theory in ecology. General Systematics, 3, 3671 (1958).

Marko, V., B. Keresztes, M.T. Fountain and J.V. Cross: Prey availability, pesticides and the abundance of orchard spider communities. Biological Control, 48, 115-124 (2009).

Marshall, E.J.P., V.K. Brown, N.D. Boatman, P.J.W. Lutman, G.R. Squire and L.K.Ward: The role of weeds in supporting biological diversity within crop fields. Weed Rese., 43, 77-89 (2003).
Montgomery, G.A., R.R. Dunn, R. Fox, E. Jongejans, S.R. Leather, M.E. Saunders and D.L. Wagner: Is the insect apocalypse upon us? How to find out. Biol. Conser., 241, 108327 (2020).

Muratet, A. and B. Fontaine: Contrasting impacts of pesticides on butterflies and bumblebees in private gardens in France. Biol. Conser., 182, 148-154 (2015).

New, T. R. and T. R. New: Insect Species Conservation. $1^{\text {st }}$ Edn., Cambridge University Press, UK, 253 pages (2009).

Pekar, S.: Spiders (Araneae) in the pesticide world: An ecotoxicological review. Pest Manag. Sci., 68, 1438-1446 (2012).

Rands, M.R.W. and N.W. Sotherton: Pesticide use on cereal crops and changes in the abundance of butterflies on arable farmland in England. Biol. Conser., 36, 71-82 (1986).

Riechert, S.E. and T. Lockley: Spiders as biological control agents. Ann. Rev. Entomol., 29, 299-320 (1984).

Saenz-Romo, M.G., A. Veas-Bernal, H. Martínez-García, R. CamposHerrera, S. Ibáñez-Pascual, E. Martínez-Villar and V.S. MarcoMancebón: Ground cover management in a Mediterranean vineyard: Impact on insect abundance and diversity. Agricul. Ecosyste. Environ., 283, 106571 (2019).

Samways, M. J., M. A. McGeoch and T.R. New: Insect Conservation: A Handbook of Approaches and Methods. Oxford University Press, England, UK (2010).

Sanchez-Bayo, F.: Impacts of agricultural pesticides on terrestrial ecosystems. Ecological Impacts of Toxic Chemicals., Bentham Science Publishers Ltd, USA, pp. 63-87 (2011).

Shah, M. A. and A.A. Khan: Assessment of coccinellid biodiversity under pesticide pressure in horticulture ecosystems. Indian J. Entomol., 76, 107-116 (2014)

Shannon, C.E. and W. Wiener: The Mathematical Theory of Communication. University Illinois Press. Urban, 324 (1949).

Simpson, E.H.: Measurement of diversity. Nature, 163, 688 (1949). https://doi.org/10.1038/163688a0

Singh, N.N. and S. Rai: Relative abundance of different coccinellids in mustard ecosystem. Indian J. Ent., 62, 422-426 (2000).

Sisterson, M.S., D.P. Dwyer and S.Y. Uchima: Insect diversity in vineyards, almond orchards, olive orchards, alfalfa fields, and pastures in the San Joaquin Valley of California. J. Ins. Conser., 24, 765-777 (2020).

Van Klink, R., D.E. Bowler, K.B. Gongalsky, A.B. Swengel, A. Gentile and J.M. Chase: Meta-analysis reveals declines in terrestrial but increases in freshwater insect abundances. Science, 368, $417-$ $420(2020)$.

Van Lenteren, J.C.: Success in biological control of arthropods by augmentation of natural enemies. In: Biological control: Measures of success. KluwerAcademic Publisher, Dordrecht, 77-103 (2000).

Yang, L., L. Xu, B. Liu, Q. Zhang, Y. Pan, Q. Li and Y. Lu: Non-crop habitats promote the abundance of predatory ladybeetles in maize fields in the agricultural landscape of northern China. Agricult. Ecosys. Environ., 277, 44-52 (2019). 